\title{
Entangled Histories of Assi- milation: Dillon S. Myer and the Relocation of Japanese Americans and Native Americans (1942-1953)
}

\section{Saara Kekki}

University of Helsinki

\begin{abstract}
Dillon S. Myer (1891-1982) has been framed as the lone villain in incarcerating and dispersing the Japanese Americans during WWII (as director of the War Relocation Authority) and terminating and relocating Native American tribes in the 1950s (as Commissioner of Indian Affairs). This view is almost solely based on the 1987 biography Keeper of Concentration Camps: Dillon S. Myer and American Racism by Richard Drinnon. Little more has been written about Myer and his views, and a comprehensive comparison of the programs is yet to be published. This article compares the aims of the assimilation and relocation policies, especially through Myer's public speeches. They paint a picture of a bureaucrat who was committed to his job, who held strongly onto the ideals of Americanization and assimilation, and who saw "mainstream" white American culture as something for all to strive after, but who was hardly an utter racist.
\end{abstract}

Keywords: Japanese Americans, Native Americans, assimilation, relocation, Dillon S. Myer

Some thirty years ago, historian Richard Drinnon came across an overlooked connection: Dillon S. Myer, a long-term government civil servant, had led both the War Relocation Authority in charge of the incarceration of Japanese Americans during World War II and the Bureau of Indian Affairs during the termination and relocation policies of the 1950s, thus oversee- 
ing the control and dispersal of two ethnic American minorities. Drinnon's research was published as Keeper of Concentration Camps: Dillon S. Myer and American Racism (1987), in which he framed Myer as a man whose actions were primarily guided by his racism. ${ }^{1}$ This view as well as the notion of Myer as a colorless bureaucrat carrying out President Franklin Roosevelt's orders, has prevailed in most of the research literature, and little has been done to compare the two policies. ${ }^{2}$

This article compares the resettlement programs that sought to Americanize the Japanese Americans during their World War II incarceration and the assimilation and relocation policies targeting Native Americans in the post-war United States. ${ }^{3}$ While the two groups were very different, the programs had many similarities. First, white people perceived both groups as having inferior cultural traits and pursued their transformation into something more desirable - that is, their understanding of what it meant to be "American." Second, both programs were led by Dillon S. Myer at significant points.

Dillon Seymour Myer was born in 1891 in Ohio, where he grew up on a farm and received a religious upbringing. After earning two university degrees, first in agriculture and later in education, Myer held various positions as an agricultural expert in several eastern states before his appointment as the director of the War Relocation Authority (WRA), an independent civilian agency in charge of incarcerating Japanese Americans in 1942. He was preceded in this task by Milton Eisenhower, who led the agency for the first few months of its existence. Eisenhower and Myer were colleagues from the US Department of Agriculture, and several other higher officials in the WRA hailed from that department. ${ }^{4}$

As the legal scholar Eric Muller has pointed out, in research literature the WRA has typically been treated as a separate venture, unconnected to pre-

1 Richard Drinnon, Keeper of Concentration Camps: Dillon S. Myer and American Racism (Berkeley: University of California Press, 1987).

2 See, for example, Kenneth R. Philp, "Dillon S. Myer and the Advent of Termination: 1950-1953," Western Historical Quarterly 19, no. 1 (1988): 37-59.

3 Various stages of research for this article have been financially supported by the Finnish Cultural Foundation, Kone Foundation, and the University of Helsinki Faculty of Arts. The author wishes to thank her reviewers for insightful feedback.

4 Drinnon, Keeper of Concentration Camps, xxiv-xxv, 12-19, 25; Eric L. Muller, "Of Coercion and Accommodation: Looking at Japanese American Imprisonment through a Law Office Window," Law and History Review 35, no. 2 (2017): 171-187. 
vious policies or administrative structures. ${ }^{5}$ In reality, its officials, including those at the top, had extensive experience with leading people. Similarly, scholarship has by and large neglected a thorough comparison of the "relocation" programs or the agencies conducting them. ${ }^{6}$ In addition to sharing officials and ideological aims, the programs were executed in similar ways. In both cases, "field offices" were established to help the resettlers (those relocated away from their former homes) to find employment and housing. Japanese and Native American resettlers both had to go through a series of interviews to determine their suitability for the programs, and both were equipped with instructional pamphlets on how to conduct themselves in their new home towns.

While Myer's role and character are the subject of Richard Drinnon's study, which depicts him as an out-and-out racist, in this article I aim to draw a more balanced interpretation of Dillon S. Myer based mostly on his public speeches. I will also touch upon Myer's correspondence during his years in office. The speeches were delivered at a diverse array of venues, both by invitation and in talks open to public, and to diverse audiences. At times, Myer spoke to an audience already sharing his views, such as the Christian organizations at Buck Hill Falls, Pennsylvania, in 1951, while at other times the audience consisted of some of the most vocal opponents of his goals, as was the case with the American Legion at Indianapolis in $1943 .^{7}$

At WRA, Myer was in charge of the ten incarceration camps confining 120,000 Japanese Americans, the majority of whom were United States citizens. While running the camps, Myer and the WRA became proponents of

5 Muller, "Of Coercion and Accommodation," 391-399.

6 Laura Sachiko Fugikawa and Karen Leong have made openings in this direction, but there have been no major publications as a result of their research. Leong has co-authored an article focusing on the Gila River Indian Community and the Japanese American incarceration camp on their lands. Karen Leong and Myla Vicenti Carpio, "Carceral Subjugations: Gila River Indian Community and Incarceration of Japanese Americans on Its Lands," Amerasia Journal 42, no. 1 (2016).

7 Dillon S. Myer speech to Combined Assemblies of the Division of Christian Life and Work of the National Council of the Churches of Christ [hereinafter NCCC] at Buck Hills Falls, Pennsylvania, December 12, 1951, 2-4, National Archives, Washington, DC, Record Group [hereinafter RG] 75, Office of the Commissioner of Indian Affairs [hereinafter OCIA], Commissioner Dillon Myer files [hereinafter DM], Desk File: Organizations-Window Rock AO, Box 3; "The Relocation Program," an address by Dillon S. Myer to the State Commanders and State Adjutants of the American Legion, Indianapolis, Indiana, November 16, 1943, Harry S. Truman Library, Independence, Missouri [hereafter HSTL], Dillon S. Myer papers [hereinafter DSM]. http://www.trumanlibrary.org/whistlestop/study_collections/japanese_internment/docs.php. 
dispersing the Japanese Americans across the United States and preventing them from forming ethnic communities after the war. When Myer became the Commissioner of Indian Affairs in 1950, he directed the agency during the years that led to the termination and relocation policies with much the same aims: removing the special status of native tribes and convincing Native Americans to relocate to different parts of the country away from reservations.

\section{Japanese Americans and Native Americans before World War II}

Many historical and cultural traits kept Japanese Americans and Native Americans apart as communities. Large numbers of Japanese immigrants began arriving to the United States only at the turn of the twentieth century, amidst an increasingly anti-Asian sentiment. Native Americans obviously lived on the continent before the first European immigrants, which renders their status different both on practical and mental levels. The United States actually had formal government-to-government relationships with dozens of Native American tribes. Negotiations regarding the status of a tribe, possible termination, and other issues were thus held between the federal government and each tribal government, although on an ideological level the US government tended to consider all tribes as coming from the same background and conditions. Similarly, upon initiating a program of incarceration, the government classified all people of Japanese ancestry as hostile aliens, despite the large number of native-born citizens. Being at war with Japan meant that there were no direct negotiations between the United States and Japan regarding the treatment of Japanese nationals, the Issei. Instead, the Spanish consul reported on the affairs of the Issei in the incarceration camps.

The Japanese were a relatively homogenous group. Having arrived in the United States during the course of just three and a half decades, between 1890 and 1924, they were also homogenous in terms of age. ${ }^{8}$ This is particularly true of the second-generation Nisei, most of whom were born between 1916 and 1930. ${ }^{9}$ Adding to the homogeneity of the Nisei and the Japanese

8 Because Japan was isolated, there were few Japanese immigrants in the US prior to 1890. Opposition to Japanese immigration led to the Gentlemen's Agreement of 1907, which effectively put an end to Japanese immigration.

9 The Nisei, or second-generation Japanese Americans, David Yoo argues, can truly be treated as a gen- 
Americans in general, most continued to actively speak Japanese and practiced the Buddhist religion. The Japanese were also racially homogenous, because miscegenation laws in California and Oregon prohibited Asians (and blacks) from marrying whites until 1948 and 1951, respectively. ${ }^{10}$

Native Americans, on the other hand, were extremely heterogeneous. There existed hundreds of tribes, languages, and religions, and most importantly, Native Americans identified with these tribal units. The feeling of pan-Indianism, while not a new phenomenon, only began to manifest itself properly during the $1960 \mathrm{~s}$. When the termination policy was adopted in 1953, some tribes had been influenced by Euro-American expansionist politics and civilizing programs for centuries, while others had been confined to reservations for less than eighty years. Their degree of assimilation hence varied remarkably across the country. Compared to Japanese Americans, much racial mixing had taken place, and only sixty percent of Native Americans were classified as "full-blood" in 1940.1"

Nevertheless, there were also several similarities in the groups' pre-war conditions. Both mostly lived in communities consisting of members of their own race (in the case of Native Americans, more precisely of their own tribe).$^{12}$ They were almost exclusively educated by white Americans with Protestant values in mind, although a majority in both groups professed some minority religion (namely Buddhism or tribal religions).

eration. As a point of distinction from other minorities, second-generation Japanese Americans not only shared the experience of having been born in a country not native to their parents, but they also shared the experience of growing up in the same years. David Yoo, Growing up Nisei: Race, Generation, and Culture among Japanese Americans of California, 1924-49 (Urbana: University of Illinois Press, 2000), 3.

10 It should be noted that there was also strong social pressure in the Japanese American community against marrying someone who was not of Japanese origin. Paul Spickard, Japanese Americans: The Formation and Transformations of an Ethnic Group, Revised ed. (New Brunswick, N.J.: Rutgers University Press, 2008), 35.

11 Alison R. Bernstein, American Indians and World War II: Toward a New Era in Indian Affairs (Norman: University of Oklahoma Press, 1991), 86.

12 The 1940 census found that 89 percent of Japanese Americans lived in the three West Coast states. Although many lived outside the actual urban Japantowns, their networks were often predominantly Japanese. The same year, 75 percent of Native Americans lived in eight Midwestern or Western states, and only five percent lived outside reservations throughout the country. U.S. Department of Commerce, Bureau of the Census, "Sixteenth Census of the United States: 1940, Population, Volume II: Characteristics of the Population, Part 1" (Washington, DC: Government Printing Office, 1942), 21. Race, of course, is a complex and complicated concept, and I acknowledge that the data does not lend itself to straightforward interpretation. See, for example, Spickard, Formation and Transformations, 2-7. 
The paths of Japanese Americans and Native Americans crossed during World War II. Once President Franklin D. Roosevelt signed Executive Order 9066 banning Japanese Americans from the West Coast, Commissioner of Indian Affairs John Collier proposed to the WRA that Japanese "relocation camps" be established on Indian lands. ${ }^{13}$ His vision was that the camps would develop reservation lands, thus benefitting Native Americans after the incarceration period had ended. He also believed that the Bureau of Indian Affairs (BIA) had the necessary experience in dealing with a racial minority group. Two of the camps, Poston and Gila River in Arizona, were located on lands leased from local native tribes. In the end, however, Native Americans benefitted little from leasing their lands to the WRA, aside from the rent paid to them. Dillon S. Myer was reluctant to develop surplus land for farming, and after the closing of the camps, buildings were torn down instead of being handed over to the Native Americans. There was very little interaction between the Native Americans and the Japanese, partly because Myer emphasized the camps as way stations, and he discouraged the inmates from forming ties with local Native Americans since the community was meant to be temporary. ${ }^{14}$

\section{Locked-Up Japanese Americans}

On February 19, 1942, President Franklin D. Roosevelt signed Executive Order 9066, authorizing the exclusion of Japanese Americans from the West Coast. Weeks later, he ordered the establishment of the War Relocation Authority to "look after" the Japanese Americans after their removal. Dillon S. Myer took over the WRA in June 1942, after the resignation of its first director, Milton Eisenhower.

13 The terminology relating to the eviction of Japanese Americans varied from "evacuation" and "relocation" to "concentration." Most commonly, the incarceration camps were called relocation centers. Today, the debate continues over whether these camps should be called internment, incarceration, or concentration camps. I have settled with the word "incarceration" and "inmate." To refer to the process of moving away from the camps, contemporary authorities usually used, again, the term "relocation," but to keep the terminology clear, I use the word "resettlement." See, for example, Brian Masaru Hayashi, Democratizing the Enemy: The Japanese American Internment (Princeton: Princeton University Press, 2004); Karen L. Ishizuka, Lost \& Found: Reclaiming the Japanese American Incarceration (Chicago: University of Illinois Press, 2006); Karen L. Ishizuka, "What's in a Word? History, Violence, and Erasure When the Words Are 'Japanese Internment' and 'Muslim Registry'," https:/rewire.news/article/2016/11/22/word-historyjapanese-internment/.

14 Bernstein, American Indians and World War II, 82-85. 
President Roosevelt authorized the actions of the WRA, but he remained disinterested in the incarceration or relocation processes and met only once with Myer during the war. He let lower-level officials handle publicity issues and would not speak favorably of the inmates, even when other administrators asked him to do so to demonstrate his support for the WRA policy. When Roosevelt finally stepped up to publicly praise the Americanism of the inmates, they had been incarcerated for a year and public opposition against the Japanese Americans had increased tremendously. ${ }^{15}$

Although the original purpose of Executive Order 9066 was to quiet antiJapanese hysteria, it did the opposite, suggesting to the general public that Japanese Americans indeed were suspicious and disloyal. It appeared that only confinement would provide a satisfactory solution to the "Japanese problem" during the war. This ran contrary to the visions of Milton Eisenhower and John Collier to establish planned communities for the inmates. ${ }^{16}$

Many Congressmen spent the war years drafting plans for the exportation of all Japanese Americans, ${ }^{17}$ but most authorities in the field focused on the eventual closing of the incarceration camps. Myer, in particular, started a strong public campaign for the Americanization of the inmates, particularly the first generation Issei. His promotion of the program consisted of two main elements: the undemocratic nature of detaining loyal citizens and the harmful impact incarceration had on the Americanism of the inmates. His statements were consistently in line with New Deal liberalism, which believed in the "common man" and advocated an individual's right to pursue happiness. ${ }^{18}$

The WRA employed anthropologists, or "community analysts," both in Washington and in each of the ten camps. Their task was to generate information about the functioning of the inmate communities, which in turn was to help the government in policy-making. Importantly, as the anthropologist Orin Starn argues, they were also to promote a "positive image"

15 Greg Robinson, By Order of the President: FDR and the Internment of Japanese Americans (Cambridge: Harvard University Press, 2001), 245.

16 Ibid., 130-131.

17 While a few Congressmen throughout the war years spoke in favor of Japanese Americans, their opponents dominated the majority of debates.

18 It must, again, be emphasized that the definition of happiness may have been very narrowly defined from a white male perspective, but it was, nevertheless, a sound vision of many of these bureaucrats that they were "doing the right thing." 
of incarceration and Japanese Americans. ${ }^{19}$ Many of them had an academic background in acculturation studies and this showed in their analyses. ${ }^{20}$

The role of these anthropologists should not be underestimated. Although their role was not public, and they typically did not represent the WRA outside the camps, my analysis of Dillon S. Myer's speeches shows that there were many parallels in the phrases used in anthropologists' reports and in Myer's public speeches. ${ }^{21}$ Furthermore, it became evident throughout the reading of the archival records that the anthropologists were quite detailed in their description of community sentiments, and while they usually refrained from making direct recommendations, their thoughts on matters such as resettlement, come through in their reports. ${ }^{22}$

Myer's arguments and style changed very little during his years in office. While he modified his message somewhat depending on his audience, he consistently incorporated four topics into almost every speech. Most often, he began by arguing for the rightfulness of the incarceration decision. This was necessary to obtain justification for Myer's and the WRA's work as such, but later he had to make a much more powerful argument for the disbanding of the camps, leading to the three ensuing topics. First, Myer explained why the camps were undesirable (if also initially justified), which he did by drawing in elements of American principles and ideologies. Then followed slightly more practical descriptions of how the Japanese would become American. Finally, he concluded by explaining the ways in which they could already be considered American. This was not to negate his previous arguments, but to show that this group of people had lived for decades in America and that the power of American society had, indeed, been strong enough to mold them toward its ideals. This line of thought also attempted to convince white Americans that the camps would stop the positive development of the Nisei.

In fact, Myer seemed appalled by the incarceration camps. While he called them communities, Myer declared that incarceration camps were

19 Orin Starn, "Engineering Internment: Anthropologists and the War Relocation Authority," American Ethnologist 13 , no. 4 (1986): 702.

20 Ibid., 714.

21 Saara Kekki, "Japanese American Internment: Spectacularization, Americanization, and the Model Minority Myth" (MA thesis, University of Helsinki, 2009), 29-46.

22 For the anthropologists' reports, see Japanese American Evacuation and Resettlement Records 1930-1974, Bancroft Library, Berkeley, California. Finding aid available through Online Archive of California, http:// oac.cdlib.org/findaid/ark:/13030/tf5j49n8kh. 
"undesirable institutions," where residents lived "an unnatural and unAmerican sort of life." It remains a matter of speculation whether he meant that the restriction of freedom was un-American or whether he was more concerned about the unusual composition of the camp communities, consisting as they did of Japanese people only. He appealed to his audience to remember democratic principles: "Keep in mind that the evacuees were charged with nothing except having Japanese ancestors." Despite speaking for the resettlement of inmates from the camps, a fear of disloyal activity was still present. Myer continued to believe that the "segregation of loyal Americans from the disloyal element is essential." ${ }^{23}$ This conviction, not only of Myer but of most officials and the general public, persisted throughout the war and resulted in the designation of the Tule Lake camp as a segregation unit. ${ }^{24}$

Apart from the requested confinement of the "disloyal element," Myer argued against the incarceration of loyal people. He frequently returned to the concept of "the American way" to win supporters for resettlement. "The American way," Myer argued, was not to "have children grow up behind barbed wire," under conditions "which make a mockery out of principles we have always cherished." More generally, the American way was to be democratic and guarantee equal opportunity to all those who adhered to American principles. In the camp environment, such principles were difficult to maintain. According to Myer, loyalty "cannot flourish in an atmosphere of suspicion and discrimination." ${ }^{25}$

Myer, however, had "faith in the American way of life and in the melting pot tradition on which this nation has developed." These principles would cause the mainstream to accept the settlement of the Japanese into new communities. ${ }^{26}$ The WRA could not forcefully resettle the inmates into

23 Myer, “An Anniversary Statement," March1943, HSTL, DSM. http:/www.trumanlibrary.org/whistlestop/ study_collections/japanese_internment/docs.php

24 The segregation took place after completing a "loyalty questionnaire," in which inmates were requested to swear unqualified allegiance to the United States. Issei found this problematic, because they did not qualify for American citizenship, and thus, feared a positive answer would make them stateless if the United States were to lose the war and Japan were to re-examine their permission to return to Japan. Many Nisei were insulted by the implication that they would be loyal to any other country than that of their birth. As a result, about 12,000 people registered a "no" response and were moved to Tule Lake. Of those refusing to swear allegiance, over 4,000 were repatriated or expatriated to Japan, although some later returned to the United States. Michi Nishiura Weglyn, Years of Infamy: The Untold Story of America's Concentration Camps (New York: Morrow, 1976), 260-269.

25 Myer, "Speech over the National Broadcasting Company network," July 15, 1943, HSTL, DSM.

26 Myer, “The Relocation Program,” November 16, 1943, HSTL, DSM. 
mainstream America or take sole responsibility for educating good Americans. Americans themselves must see that it is the right thing to do. Of course, Myer acknowledged, "democracy is never an easy form of government. [...] it can be made to operate successfully only if the people have the necessary energy, ingenuity and especially courage to make it work." 27 This was a subtle hint at the responsibility of the general public to show their Americanness. Myer's images, however, were powerful. In a time of war, few people would miss an opportunity to show courage and to do their share. Furthermore, Myer scolded certain Americans for discriminating against other American citizens merely "for accidents of ancestry," another popular image of his. ${ }^{28}$

Myer repeatedly noted that the United States could not keep its citizens locked up in camps when the country was involved in a war to stop such treatment elsewhere. One of his most powerful statements on appealing to democratic ideals he repeated several times: "Let's not deal with the problem as Hitler would handle it under his Nazi regime, or as Tojo would deal with it in Japan. Let's do it in the American way." 29 Herein, he posed a strong challenge for Americans: How might they avoid reducing themselves to the level of their enemies? The answer, Myer suggested, was that the Japanese Americans need and should receive "help" in assimilating.

Rather than emphasizing the rights of the inmates and making them the center of focus, he gave the role of the protagonist to mainstream America. If the Japanese were kept in the camps until the war was over, Myer said, the country would face an enormous problem. The end of the war would result in the return of the inmates "to the place they called home-and the Little Tokyos would probably spring up again, with all their undesirable features." ${ }^{30}$ This was in clear contrast to the speeches he made as Commissioner of Indian Affairs, in which he had emphasized the responsibility of Native Americans to improve their conditions and did not seem to worry about their returning to reservations.

27 Myer, "The Facts about the War Relocation Authority," January 21, 1944, HSTL, DSM.

28 Myer, "Relocation Problems and Policies," March 14, 1944. Later, Myer used the same image at least in "Racism and Reason," October 2, 1944; "A Message from the Director of the War Relocation Authority [to evacuees resident in relocation centers]," January 1945, HSTL, DSM.

29 Myer, "March of Time," June 24, 1943, HSTL, DSM.

30 Myer, "The Truth about Relocation," August 6, 1943, HSTL, DSM. 
Thus, to justify his call for acceptance of the resettlement program, Myer kept reminding his audiences of the founding ideals of the nation. Americans must portray their excellence as a nation by tolerating, even helping out, all groups in their country. People in need-in this case, the Japanese Americans - should be integrated into the greatness of America. This, again, was a demonstration of his New Deal liberal ideology — of the idea that people deserve the right to pursue the American dream, however abstract it may be.

Myer's statements regarding Americanization and assimilation became more frequent as the war progressed. These comments intertwined with the rest of Myer's rhetoric, which aimed at generating a more approving climate for the "final relocation" of the inmates.

He noted that the "almost complete assimilation" of the Japanese Hawaiians had encouraged scores of young men to volunteer for the army. In the continental United States, however, racism and discrimination had spurred negative responses to service. He felt that assimilation was a desirable outcome for immigrants, but he also admitted that the conditions for assimilation had not been favorable on the mainland.

To counter the assumption of unassimilability as the root of discrimination against the Japanese Americans, Myer repeatedly argued that viewing the American-born Nisei as "Japanese" would be "equivalent to asserting that American institutions exercise a less potent influence over the youthful mind than the transplanted institutions of the Orient." To the contrary, Myer pledged his faith in American institutions, to which "few human minds can be exposed to [...] without absorbing the rich heritage of American life." Strong proof of this notion was the fact that the inmates had "reached out" to American institutions, such as the Boy Scouts, even "in such an artificial atmosphere." ${ }^{11}$ This was a very typical view of the WRA officials: that the Nisei were highly assimilated, while the Issei were for the most part unassimilated.

Nevertheless, while educational programs in the camps promoted Americanism, Myer argued that they "can never be wholly effective" in a camp environment. "The influences that operate every day and every week to make us a distinctive people on the face of the globe cannot be reproduced within an atmosphere of restriction," he stated. The purpose of the reloca- 
tion program was to disperse the population to "other parts of the country, where they can be absorbed readily." 32

The job of the WRA, in Myer's view, was to ease the relocation of Japanese Americans from the centers "into normal communities where they can develop into normal men and women." In this context, Myer continued to argue for the potency of American institutions, repeating his earlier criticism of those who thought that "merely because an individual is of Japanese extraction, he is somehow immune to the effect of our public school system." 33

Thus, Myer said, the American public must stop looking for ways in which the Japanese are different, and rather embrace their similarity with the rest of the Americans. Myer felt that although the resettlement endeavor might be difficult, "it is a job that must be accomplished if the American way of life is to have real meaning to these people." ${ }^{34}$ Eventually, an "American in the full sense of the word [...] acts with goodwill toward his neighbors, makes sacrifices for his country, does the things that he believes help all races, creeds and groups to work together and make this a strong nation." 35 This can be interpreted as a message to Japanese Americans, white Americans, and foreigners. On the surface, Myer provided a description of a "good American," a description of the Japanese Americans once properly assimilated. At the same time, it was a plea to the general public to act in an American way, that is, by allowing the inmates to resettle. Finally, it was a reminder to outsiders, friends, and enemies alike that the actions of the United States are guided by a higher creed and should be taken seriously.

Myer also had a message for the inmates in camps. Instead of "breaking their present connections and moving back to their old home communities," they should seriously consider moving east. ${ }^{36}$ Confusingly, however, Myer did not explain how their moving across the country would amount to retaining all the "present connections" and benefit the inmates in any way. Myer's tendency to simultaneously promote a policy of assimilation and Americanization as well as the already extraordinary Americanism of

32 Myer, "The Truth about Relocation"; "The Relocation Program," HSTL, DSM.

33 Myer, "Relocation Problems and Policies," HSTL, DSM.

34 Myer, "One Thousandth of a Nation," March 23, 1944, HSTL, DSM.

35 Myer, "Racism and Reason," HSTL, DSM.

36 Myer, "A Message from the Director." 
the Japanese Americans further confused his argument at this point. ${ }^{37}$ It is as though Myer thought that the "American character" of the Nisei could disappear. The large number of citizenship renunciations can be interpreted as such - or, as I do, mostly as an expression of frustration and disillusionment with one's home country.

For years following the war, official Japanese American civil rights organizations, namely the Japanese American Citizens League (JACL), which represented the younger generation, viewed Myer as a benefactor who saved the inmates by promoting their return to normal life. In 1946, the JACL organized a banquet in Myer's honor, praising him as a "champion of human rights and common decency." ${ }^{8}$ They viewed Myer as having played a crucial role in their eventual resettlement into American life, and the fact that after incarceration their status in society slowly began to rise. ${ }^{39}$

Myer lost his status as the hero of the Japanese Americans during the 1970s and 1980s redress campaign, and he became one of the main individual targets of the movement. The third-generation Sansei hardly saw him as a benevolent hero, but instead held him responsible for the troubles of the Nisei and the disintegration and deprivation of post-war Japanese American communities. Myer died in 1982, amidst the hearings of the Commission on the Wartime Relocation and Internment of Civilians, in which the JACL was seeking to convict Myer for his role in their incarceration. ${ }^{40}$

\section{"The Indian Problem"}

World War II was also a watershed in Indian-white relations. Native Americans were actively involved in the war effort, inevitably leading to increased

37 Most Nisei were, in fact, extremely Americanized despite their frequent exclusion from mainstream society. They had been educated in the American public schools, but their parents were also adamant that they assimilate culturally. See, for example, Yoo, Growing up Nisei.

38 Dillon S. Myer, Uprooted Americans. The Japanese Americans and the War Relocation Authority during World War II (Tucson: University of Arizona Press, 1972), 342.

39 The JACL was a controversial organization throughout the incarceration years and thereafter. Many felt that the organization had sold Japanese American civil rights too cheaply by conceding to incarceration. While a good number of people supported the JACL, its stand was by no means universally approved. See, for example, Frank S. Emi, "Protest and Resistance: An American Tradition," in A Matter of Conscience, ed. Mike Mackey (Powell: Western History Publications, 2002); Yosh Kuromiya, "The Fourth Option," ibid.

40 Drinnon, Keeper of Concentration Camps, 251-254. 
contact between natives and whites.$^{41}$ Native American veterans used their positive image in the wider American society to emphasize their willingness to become full members. They argued that their status should be improved; they had been "good enough" to fight the war, and they should be "good enough" to own property and enjoy full civil rights. ${ }^{42}$

The government found in the veterans fertile soil to promote assimilation, and it began making plans to offer work placement for returning veterans. Acting Commissioner of Indian Affairs Barton Greenwood suggested in 1945 that the veterans be moved as far as possible from their original environment to prevent them from easily returning to the reservations ${ }^{43}$ This thought of relocating the veterans, and later all other Native Americans, coincided and overlapped with the desire to end federal-Indian relations altogether, that is, of terminating the special status of Native Americans.

United States Indian policy was expensive to maintain, and all sectors of government faced budget cuts after the war. The first two commissioners after the reformer John Collier were uncontroversial figures among the whites as well as the Native Americans, and they mostly carried out cosmetic changes in Indian affairs. ${ }^{44}$ Dillon S. Myer, on the other hand, revamped the BIA administration in his three years in office, with the administration becoming fully committed to termination. ${ }^{45}$ Bills calling for the change in status of individual tribes were passed during Myer's years in office, but termination of all Native Americans tribes was adopted as official policy by the United States government (and subsequently by participating tribes) shortly after Myer's term, in August 1953.

Upon becoming Commissioner of Indian Affairs, Myer received the customary congratulatory letters from former colleagues and several Native Americans tribes. Japanese Americans approached him to express their encouragement and confidence in him. Reverend Daisuke Kitagawa was

41 There were nearly 22,000 Native Americans serving in the US military in 1944, and some 40,000 found wartime jobs outside reservations. Francis Paul Prucha, The Great Father: The United States Government and the American Indians (Lincoln: University of Nebraska Press, 1991), 337; Bernstein, American Indians and World War II, 68.

42 Donald Lee Fixico, Termination and Relocation: Federal Indian Policy, 1945-1960 (Albuquerque: University of New Mexico Press, 1990), 14.

43 Ibid., 134. This request is very similar to those made by the authorities in the case of the Japanese Americans. See, for example, Dillon S. Myer, "The Truth about Relocation," HSTL, DSM.

44 John Collier was Commissioner of Indian Affairs 1933-1945.

45 Fixico, Termination and Relocation, 135; Prucha, The Great Father, 341. 
pleased that "at long last something really creative will be done with American Indian people." ${ }^{46}$ Mrs. Earl Tanbara wrote that Japanese Americans "know in part life on a reservation." She further complimented Myer for his work as director of the War Relocation Authority: "After your outstanding work in relocating us from the Pacific Coast, we know that [...] you will do a courageous piece of work in helping solve our Indian problem." ${ }^{47}$ These statements to Myer demonstrate that the Japanese no longer considered themselves a problem, but identified the Native Americans as still being one.

Myer identified land ownership as the main problem in Indian affairs. He claimed that the federal government was partly responsible for the issue, because Indian policy had always sought to make Indians into farmers and ranchers. This had tied them "to the land perhaps more closely than any other segment of our population." In some areas, they had been "outstandingly successful," but at the same time, such a policy prevented those uninterested in farming from moving away from reservations. ${ }^{48}$ In this sense, Myer and John Collier's views were quite similar. They differed, however, in their stand on tribal governments. Collier believed that adjustment to mainstream society could only take place through group, or tribal, processes. Myer, on the other hand, felt that tribal governments and the specific services aimed at Native Americans stifled the tribes' development toward independence and segregated them from the rest of the society. ${ }^{49}$ This hindered their chances of becoming middle-class Americans and "realizing their full potentialities." ${ }^{50}$

46 Daisuke Kitagawa to Dillon S. Myer, April 4, 1950, RG75, OCIA, DM, Desk File: Congratulations-Muskogee AO, Box 2, Folder 1: Congratulations \& Misc. Personal. Daisuke Kitagawa was a Japan-born Episcopalian reverend, who became a prominent spiritual leader among the Japanese Americans particularly during incarceration.

47 Mrs. Earl Tanbara to Dillon S. Myer, April 14, 1950, RG75, OCIA, DM, Desk File: Organizations-Window Rock AO, Box 3, Folder 1: Organizations interested in Indians.

48 Dillon S. Myer speech to Combined Assemblies of the Division of Christian Life and Work of the NCCC at Buck Hills Falls, Pennsylvania, December 12, 1951, 2-4, RG75, OCIA, DM, Desk File: OrganizationsWindow Rock AO, Box 3.

49 Fixico, Termination and Relocation, 72; Prucha, The Great Father, 335. Under Collier's commissionership, the BIA had introduced tribal governments as ways to communicate with the tribes. Later scholarship has, however, noted that tribal governments were entirely set up in accordance with white American perceptions of government. This caused friction in many tribes, as traditional leadership structures were artificially changed.

50 Dillon S. Myer speech to Combined Assemblies of the Division of Christian Life and Work of the NCCC at Buck Hills Falls, Pennsylvania, December 12, 1951, 2-4, RG75, OCIA, DM, Desk File: OrganizationsWindow Rock AO, Box 3. 
In a post-career oral history interview, Myer drew a distinction between US policies before the 1920s and those in subsequent decades, strongly identifying with the latter and dismissing the aims and results of the former. He was of the opinion that practically nothing of use had been done to "stop

the exploitation" of Native Americans and to provide them with proper education and means to assimilate..$^{1}$

To tackle the problems, Myer argued that the BIA should help Native Americans leave the reservations and take up other jobs besides those related to the land. The aid consisted of two parts. The first was a program of training and placement assistance for those who wanted to leave the reservations, while the second entailed giving guidance to those who wanted to remain on the reservations to start developing industrial programs. The programs were quite similar to the leave programs implemented in the Japanese American incarceration camps, and Myer is said to have modeled his Indian relocation program after that of the Japanese Americans, convinced of its ultimate success. ${ }^{52}$ Both programs comprised various steps to determine the applicant's suitability, including applications and interviews. Authorities helped in finding jobs and housing and usually gave financial support during the first weeks. Both programs also included instruction manuals and classes for the relocatees..$^{53}$

In his BIA-era speeches, Myer continued to appeal to his listeners with imagery of working together, familiar from his WRA speeches. His rhetoric was subtler, however. He made fewer direct references to American ideals, rather only alluding to them. For instance, in one of his first speeches,

51 Dillon S. Myer, "Oral History Interview with Dillon S. Myer, Director, War Relocation Authority, 19421946; President, Institute of Inter-American Affairs, 1947-50; Commissioner of Indian Affairs, 1950-53," interview by Helen S. Pryor, University of California Bancroft Library/Berkeley Regional Oral History Office, 286-287, quote on page 287, https://www.trumanlibrary. org/oralhist/myerds.htm.

52 Kenneth R. Philp, "Stride toward Freedom: The Relocation of Indians to Cities, 1952-1960," The Western Historical Quarterly 16, no. 2 (1985): 179; Fixico, Termination and Relocation, 66-67. A leave program of sorts was also implemented at an earlier stage of handling Native American affairs. Already in the late nineteenth century, the US authorities, more precisely Director Captain Richard Henry Pratt of Carlisle Indian School, developed an "outing system" designed to send Native American students outside the boarding school to work for white employers. This practice spread to other Native American schools as well, as it was seen as an effective way of re-enforcing skills and Americanism learned at school. See Michael C. Coleman, American Indians, the Irish, and Government Schooling: A Comparative Study (Lincoln: University of Nebraska Press, 2007), 128.

53 Fixico, Termination and Relocation, 136. 
given to the National Congress of the American Indian (NCAI), he said "One of my deepest concerns is that the Indians of the United States shall participate in shaping the answers to the problems that confront them and aid in determining the rules that guide them in their relationship with the Federal Government." ${ }^{54}$ While this statement clearly suggests that Myer wanted Native Americans to be involved in policy-making, he also referred to one classic American ideal: self-reliance, every man for himself. Speaking to Christian organizations, Myer summed up the purpose of the relocation program and his personal ideals very powerfully: "[...] provide the institutionalized Indian youngsters with the kind of home and community life they need if they are to grow up as self-reliant and civic-minded American citizens." ${ }^{55}$ In addition to suggesting that reservation life resulted in a form of institutionalization, Myer could be interpreted as promoting the closure of Native American boarding schools in favor of foster care and adoption. There is, however, no direct reference to such thinking in any of Myer's speeches, and the federal Indian Adoption Project was initiated only after Myer's time at the BIA, in $1958 .^{56}$

Being self-reliant and civic-minded were key to how Myer characterized good citizenship, but this sentence entails plenty of evaluation and criticism of Indian affairs and Native American communities. Indian policy, with its reservations and services provided only for Native Americans, had caused reservation life to become more or less institutionalized-despite the fact that reservations were in theory communities that people could move into and out of rather freely. This perception is similar to what Myer had said about the Japanese American incarceration camps. At the same time, he hinted at disapproval of Native American home and community life, which shows he did not understand the cultures he was dealing with. While many Native American communities in the 1950s suffered from poverty, illnesses, and alcoholism, they continued to be traditionally tightly-knit. Strong and extensive family networks only began to break down more decisively once the relocation program started to impact the various communities.

54 "Statement of Commissioner of Indian Affairs Dillon S. Myer before the National Congress of American Indians," Bellingham, WA, August 29, 1950, 1 [hereinafter NCAI 1950], RG75, OCIA, DM, Box 3, Folder: Speeches.

55 Address by Dillon S. Myer, Commissioner of Indian Affairs, before the Combined Assemblies of the Division of Christian Life and Work of the NCCC, Buck Hills Falls, Pennsylvania, December 12, 1951, 9. See also Address of Commissioner D. S. Myer to Navajo Tribal Council, September 13, 1950, RG75, OCIA, DM, Box 3, Folder: Speeches.

56 The author wishes to thank her anonymous reviewer for pointing out this alternative interpretation. 
While Myer frequently emphasized that the purpose of the programs was to improve the health and financial status of Native Americans, he occasionally suggested areas in which they themselves needed to make improvements. Often his views were belittling and paternalistic: "And as they move to take their places by the side of their fellow-Americans they will learn the techniques and procedures of providing for themselves and of living more adequately in our fast-changing industrial civilization." ${ }^{57}$ Myer probably wanted to say that the BIA programs would elevate Native Americans to a new standard of living, but he also blatantly stated that they were indeed wards of the government, incapable of taking care of themselves without assistance.

The termination policy and particularly the relocation policy have usually been taken as examples of assimilationism. In many ways, however, Myer and the BIA seemed to have been more focused on the task of cutting government responsibility in Indian affairs. The policies were meant to persuade Native Americans to move away from reservations in order to ensure a higher standard of living, but already in 1951 Myer acknowledged that not everyone would want to move, and so BIA "policies and our programming must necessarily be broad enough to meet the needs of both types of Indian people." He also claimed to be impressed by "the tremendous diversity $[\ldots]$ among the several Indian tribes and groups." ${ }^{58}$ This suggests a rather tolerant view of Native Americans, an appreciation of the fact that the various tribes and groups are different.

This tolerance was not only a tactic employed directly toward the Native Americans. Speaking to a convention of Christians, Myer expressed his hope that church organizations would help accommodate Native Americans in their transition to urban life: "They will need help in finding suitable meeting places for recreational and community activities. They need to know how they can find other Indians who may be in the community." 59 It is remarkable that Myer talks about the right and significance of finding new Indian networks for people he is trying to make less Indian. In my interpretation, this does not mean that Myer was proposing segregation,

57 Myer, NCAI 1950, 3, RG75, OCIA, DM, Box 3, Folder: Speeches.

58 Address by Dillon S. Myer, Commissioner of Indian Affairs, at the Eighth Annual Convention of the National Congress of American Indians, St. Paul, Minnesota, July 25, 1951 [hereinafter NCAI 1951], 11; 13, RG75, OCIA, DM, Box 3, Folder: Speeches.

59 Myer, NCCC, 6, RG75, OCIA, DM, Box 3, Folder: Speeches. 
because at the same time he talked about incorporating Native Americans into existing Boy Scout groups and other institutions. In conducting his WRA policy, Myer always emphasized that Japanese Americans should not "congregate" in their new hometowns. This change may be proof that he had learned from experience that ethnic organizations in fact helped in the adjustment phase and eventual assimilation.

It appears that Myer and the rest of the administration and politicians saw the dissolving of reservations and tribes as their main goals. Native American cultures would be tolerated, if only Native Americans themselves would become more individualistic:

So one of the biggest problems facing the Government is to assist the Indian in moving into the main stream of American life and breaking that pattern of isolation. Reservation life leads to a continuation of certain old ways of life and nowadays leads to a welfare type of state for the simple reason that there is not enough work available in many of the reservation areas. So poverty, problems of relocation, problems of education, problems of health and sanitation all go more or less hand in hand. ${ }^{1}$

This is the most personal of Myer's statements. Although the official policy sought also to create jobs on the reservations to support those who were not willing to move, Myer clearly thought that the root of the problems lay in the existence and structures of reservations.

In the context of more than a hundred years of assimilationist Indian policy, Myer's views hardly stand out. The whites of the early twentieth century believed that Native Americans as a race would become extinct, and Myer continued to believe in the demise of their cultures: "I think the Indians are on the way out as a separate or isolated people, but it may take hundreds of years." He also made a prediction on the future of Native American cultures that was proven wrong mere decades later: "The old rites that were practiced by the Indians in initiating young men into the tribe are going out of existence pretty fast. [...] I am sure that this problem of loss of interest on the part of the young people and maintaining the old rites is going to be a factor in the integration process." ${ }^{.2}$ In the twenty-first century, we have on

1 Memorandum to Bureau of Indian Affairs, March 20, 1953. Quoted in Myer, "Oral History Interview with Dillon S. Myer," 290.

2 Ibid. Myer's use of the word "problem" refers to his discussions with Pueblo elders, who saw the lack of interest as a problem. 
the contrary seen the rebirth of many Native American traditions and rites. On the one hand, this might be interpreted as the failure of BIA policies, but on the other it also speaks for a change in society. Hybrid identities have become more acceptable, both for society at large and for many individuals, which manifests itself in the re-adoption of near-forgotten cultural forms.

Compared to his role in the War Relocation Authority, Myer did not have to justify his position as Commissioner of Indian Affairs. The perception of an existing Indian problem was widespread across the administration and the general public, and it had to be solved. In similar fashion as with the WRA, however, Myer's duty was, once again, to make an office redundant. In the case of the WRA, he succeeded, both because the Supreme Court ordered the closure of camps and because the WRA worked to get inmates out of the camps. With Indian affairs, however, the task was too big to be carried out within a short period of time, and in less than ten years the political atmosphere changed to support a subtler policy. ${ }^{3}$

Myer seems to have failed to grasp the extent of his termination and relocation efforts. The relocation of Japanese Americans - whether it should be considered a success or not-was theoretically much easier. They were a relatively homogenous group (at least culturally) of less than 120,000 people, who had been brought in ten clearly confined camps. It was much easier to track the movements of these people, and, on the other hand, to convince them of the need for relocation, because life away from the camps was guaranteed to offer the inmates at least more civil rights than their present confinement. Meanwhile, Native Americans were an artificially labeled group of some 350,000 people, who lived across the country on reservation lands guaranteed to them by treaties with the government. ${ }^{4}$ Upon being appointed commissioner, Myer set out to make the BIA redundant, but what he in fact accomplished was almost a tripling of the bureau's annual expenditure, and the trend continued throughout the 1950s. ${ }^{5}$

3 Undoubtedly the change also had to do with the fact that termination was not as easily carried out as had been hoped.

4 By artificially labeled, I mean that until the relocation program, Native Americans had mostly identified with their respective tribes, not so much as "Indians."

5 Fixico, Termination and Relocation, 73, 175-176. 


\section{Dillon S. Myer and His Legacy}

Dillon S. Myer was a controversial figure among his coworkers and the public throughout his career. For Japanese Americans, he was first viewed as a hero, then as a villain. White Americans accused him of coddling the Japanese inmates, an accusation that was often applied also to Indian Affairs in general. Later scholarship has either labeled him a colorless bureaucrat or a cold-hearted racist.

Myer himself seemed a supporter of the former image. In his 1970 oral history interview, he recounted detailed facts of his long career, but provides little analysis of the reasoning behind or the consequences of his actions. For him, his work consisted of a series of problems that had arisen before his time in office, which he tackled in the most efficient way possible. ${ }^{6}$

Myer offered only one additional personal reflection on Native Americans in the almost 400 pages of interview. In it, he concludes that he hopes that Native Americans "will be emerging as active people in politics, as lawyers and doctors and professional people of various types, because nowadays many of them are going to the same schools as white people are, and they are getting the opportunity to go to college." 7 This quotation yet again demonstrates Meyer's belief in his own "benevolence" and that he was helping his clients integrate.

In relation to Japanese American incarceration, Myer had little choice besides refusing outright his appointment as director of the WRA. Japanese Americans had been incarcerated by legislation, and his opportunities for changing the situation or conditions in the camps were limited. As Commissioner of Indian Affairs, he spent three years as part of the long history of solving the unavoidable "Native American problem." At the BIA, too, he was constrained not only by the prevalent ideology, but also by history. Long before Myer's time, it had become impossible to ignore Native Americans.

Nothing indicates that Myer supported the segregation or different treatment of Native Americans or Japanese Americans from that of white Americans. Furthermore, he did not suggest that these minorities were inherently or racially inferior, contrary to many statements made in Congress at the time. Yet there is no doubt that Myer viewed white American culture as the most desirable form of culture, one to be attained by everyone.

6 Myer, "Oral History Interview with Dillon S. Myer."

7 Ibid., 288. 
In the context of this study, it is useless to argue either for or against the general policy of assimilation. It had been the official, widely accepted, policy, especially with respect to Native Americans, already since the midnineteenth century, and it continued throughout the 1940s and 1950s. ${ }^{8}$ In other words, it was not extraordinary to desire the assimilation of either the Japanese Americans or the Native Americans. Had Myer been deeply racist, he probably would have been able to achieve a higher turnout for the voluntary expatriation of inmates. ${ }^{9}$ His Native American policies, furthermore, seem to have been driven mostly by financial reasons.

Rather than being racially motivated, Myer's rhetoric was paternalistic: he believed that his agency and his fellow white Americans had an obligation to "help" his subjects to become "better" Americans. ${ }^{10}$ While a certain degree of racial superiority is obvious in such thinking, I would rather call it ignorance than racism. Most significantly, Myer's public discourse was remarkably less racist than that of, for example, many Congressmen. In my interpretation, he was a product of his time rather than the main villain. He had an established notion of what it was to be an American, and he wanted to enable many people to become part of it: "I have some experience with the problems of minorities in our country and I know that their finest hopes and aspirations are as truly in the American tradition as those of the rest of us." 11

\section{Bibliography}

\section{Primary Sources}

Harry S. Truman Library [HSTL]. Collections accessed online, January 31, 2018. https:// www.trumanlibrary.org/whistlestop/study_collections/japanese_internment/.

8 For more about the history of Native American assimilation, see, for example, Markku Henriksson, The Indian on Capitol Hill: Indian Legislation and the United States Congress, 1862-1907 (Jyväskylä, Finland: Gummerus, 1988), 3-5, 114; Frederick E. Hoxie, A Final Promise: The Campaign to Assimilate the Indians, 1880-1920 (Lincoln: University of Nebraska Press, 1992, orig. pub. 1984).

9 More than 4,000 inmates renounced their citizenship and requested repatriation or expatriation to Japan. This included some 1,100 adult US citizens, about 1,500 aliens, and the more than 1,700 children of those classified as aliens. US citizens, however, were later able to return to the United States. Statistics on the number of individuals who returned are not available. Weglyn, Years of Infamy, 260.

10 Myer made direct references to this conviction in various speeches, for example in "Obligations of Our Heritage," October 18, 1943.

11 Myer, NCAI 1950, 2, RG75, OCIA, DM, Box 3, Folder: Speeches. 
Dillon S. Myer, "Oral History Interview with Dillon S. Myer, Director, War Relocation Authority, 1942-1946; Commissioner, Federal Public Housing Administration, 1946-47; President, Institute of Inter-American Affairs, 1947-50; Commissioner of Indian Affairs, 1950-53." Interview by Helen S. Pryor. University of California Bancroft Library, Berkeley Regional Oral History Office. Berkeley, California, July 1970. http://www.trumanlibrary.org/oralhist/myerds.htm.

Papers of Dillon S. Myer.

Papers of Philleo Nash.

Myer, Dillon S. Uprooted Americans: The Japanese Americans and the War Relocation Authority During World War II. Tucson: University of Arizona Press, 1971.

National Archives, Washington, DC.

RG75, Records of the Bureau of Indian Affairs. Branch of Relocation Services. Office Files, 1949-1961.

RG75, Records of the Bureau of Indian Affairs. Records of the Office of the Commissioner of Indian Affairs [OCIA]. Commissioner Dillon Myer files, 1950-53 [DM].

\section{Secondary Sources}

Bernstein, Alison R. American Indians and World War II: Toward a New Era in Indian Affairs. Norman: University of Oklahoma Press, 1991.

Coleman, Michael C. American Indians, the Irish, and Government Schooling: A Comparative Study. Lincoln: University of Nebraska Press, 2007.

Drinnon, Richard. Keeper of Concentration Camps: Dillon S. Myer and American Racism. Berkeley: University of California Press, 1987.

Emi, Frank S. "Protest and Resistance: An American Tradition." In A Matter of Conscience, edited by Mike Mackey, 51-61. Powell: Western History Publications, 2002.

Fixico, Donald Lee. Termination and Relocation: Federal Indian Policy, 1945-1960. Albuquerque: University of New Mexico Press 1990.

Hayashi, Brian Masaru. Democratizing the Enemy: The Japanese American Internment. Princeton: Princeton University Press, 2004.

Henriksson, Markku. The Indian on Capitol Hill: Indian Legislation and the United States Congress, 1862-1907. Jyväskylä, Finland: Gummerus, 1988.

Hoxie, Frederick E. A Final Promise: The Campaign to Assimilate the Indians, 1880-1920. Lincoln: University of Nebraska Press, 1992, orig. pub. 1984.

Ishizuka, Karen L. Lost \& Found: Reclaiming the Japanese American Incarceration. Chicago: University of Illinois Press, 2006.

- _ _. "What's in a Word? History, Violence, and Erasure When the Words Are 'Japanese Internment' and 'Muslim Registry'." https://rewire.news/article/2016/11/22/word-history-japanese-internment/.

Kekki, Saara. "Japanese American Internment: Spectacularization, Americanization, and the Model Minority Myth.” MA thesis, University of Helsinki, 2009.

Kuromiya, Yosh. "The Fourth Option.” In A Matter of Conscience, edited by Mike Mackey, 77-80. Powell: Western History Publications, 2002.

Leong, Karen, and Myla Vicenti Carpio. "Carceral Subjugations: Gila River Indian Community and Incarceration of Japanese Americans on Its Lands." Amerasia Journal 42, no. 1 (2016): 103-120. 
Muller, Eric L. "Of Coercion and Accommodation: Looking at Japanese American Imprisonment through a Law Office Window." Law and History Review 35, no. 2 (2017): 277-319.

Philp, Kenneth R. "Dillon S. Myer and the Advent of Termination: 1950-1953." Western Historical Quarterly 19, no. 1 (1988): 37-59.

- _ - "Stride toward Freedom: The Relocation of Indians to Cities, 1952-1960." The Western Historical Quarterly 16, no. 2 (1985): 175-190.

Prucha, Francis Paul. The Great Father: The United States Government and the American Indians. Lincoln: University of Nebraska Press, 1991.

Robinson, Greg. By Order of the President: FDR and the Internment of Japanese Americans. Cambridge: Harvard University Press, 2001.

Spickard, Paul. Japanese Americans: The Formation and Transformations of an Ethnic Group. Revised ed. New Brunswick, N.J.: Rutgers University Press, 2008.

Starn, Orin. "Engineering Internment: Anthropologists and the War Relocation Authority." American Ethnologist 13, no. 4 (1986): 700-720.

U.S. Department of Commerce, Bureau of the Census. "Sixteenth Census of the United States: 1940, Population, Volume II: Characteristics of the Population, Part 1.” Washington, DC: Government Printing Office, 1942.

Weglyn, Michi Nishiura. Years of Infamy: The Untold Story of America's Concentration Camps. New York: Morrow, 1976.

Yoo, David. Growing up Nisei: Race, Generation, and Culture among Japanese Americans of California, 1924-49. Urbana: University of Illinois Press, 2000. 